\title{
INVASIVE MEDULLARY THYMOMA ASSOCIATED WITH MYASTHENIA GRAVIS
}

\author{
AN UNUSUAL CASE \\ J ORGE S. REIS FILHO ${ }^{1}$, MARIA FERNANDA MILANEZI ${ }^{2}$, CHRISTIANO G. MOREIRA ${ }^{3}$, \\ LINEU C. WERNECK ${ }^{4}$, PAULO BOSCARDIN ${ }^{5}$, SERGIO OSSAMU IOSHII ${ }^{6}$, FERNANDO C. SCHMITT ${ }^{7}$
}

\begin{abstract}
Thymomas are tumors characterized by a remarkable morphological heterogeneity and variable clinical behavior. This tumor has unique clinical associations, most notably with hematological abnormalities and myasthenia gravis. According with the Müller-Hermelink criteria, there are significant differences between the histological types of thymomas and the association with myasthenia gravis. Among the different histological types, medullary thymoma is the least frequent variant associated with this autoimmune disease. In this report we describe a case of medullary thymoma presenting in a 71-year- old woman with a myasthenic syndrome.
\end{abstract}

KEY WORDS: medullary thymoma, myasthenia gravis, immunohistochemistry, Müller-Hermelink classification.

\section{Miastenia gravis em um paciente com timoma medular invasivo: relato de caso}

RESUMO - Os timomas são tumores caracterizados por grande heterogeneidade morfológica e comportamento clínico variável. Este tumor apresenta associações clínicas singulares, principalmente com doenças hematológicas e com a miastenia gravis. De acordo com a classificação de Müller-Hermelink, existem diferenças significativas entre as variedades histológicas dos timomas e sua associação com a miastenia gravis. Entre os diferentes tipos histológicos, o timoma medular é a variante menos frequentemente associada com esta doença autoimune. Neste relato, nós descrevemos caso de timoma medular em uma paciente de 71 anos de idade com síndrome miastênica.

PALAVRAS-CHAVE: timoma medular, miastenia gravis, classificação de Müller-Hermelink.

Thymomas are characterized by a remarkable morphological heterogeneity and variable clinical behavior $^{1}$. These tumors have unique clinical associations, most notably with myasthenia gravis $(\mathrm{MG})^{2}$. The classification proposed by Marino and Müller-Hermelink ${ }^{3}$ is based on morphology and histogenesis of thymomas and provides an useful clinicopathological correlation. According with this classification, there are significant differences between the histological types of thymomas and the frequency of myasthenia gravis ${ }^{1,2,4}$. Medullary thymoma is most frequently associated with hematological abnormalities, and is only rarely associated with $\mathrm{MG}^{1,2,4}$.

We report on a case of medullary thymoma associated with MG.

Serviço de Anatomia Patológica do Hospital de Clínicas (HC) - Universidade Federal do Parná (UFPR), Brasil; Instituto de Patologia e Imunologia Molecular da Universidade do Porto (IPATIMUP), Portugal; Departamento de Clínica Cirúrgica HC-UFPR ; Serviço de Neurologia - HC-UFPR: ${ }^{1}$ Residente em Anatomia Patológica - HC-UFPR, Fellow do IPATMUP; ${ }^{2}$ Patologista do IPATIMUP; ${ }^{3}$ Discente do curso de Medicina UFPR; ${ }^{4}$ Professor do Departamento de Clínica Médica e Chefe do Serviço de Doenças Neuromusculares HCUFPR; ${ }^{5}$ Cirurgião do Departamento de Clínica Cirúrgica HC-UFPR; ${ }^{6}$ Patologista do HC- UFPR, Professor Adjunto do Departamento de Patologia Médica HC-UFPR; ${ }^{7}$ Investigador Sênior e Diretor da Unidade de Patologia do IPATIMUP. Aceite: 28-agosto-2000.

Dr. Jorge Sérgio Reis Filho - Serviço de Anatomia Patológica. Hospital de Clínicas - Rua General Carneiro 181 -80060-900 Curitiba PR - Brasil.E-mail: jsreis@hotmail.com 


\section{CASE}

A 71-year-old woman presented in our hospital with progressive dysphagia, asthenia, dysphonia, bilateral palpebral ptosis and diplopia for five months. She had received the diagnosis of MG and was treated with anticholinesterasic drugs with a good response. Six months later she developed exertional dyspnea and worsening of the myasthenic symptoms despite continued treatment. A chest film obtained at that moment revealed a mediastinal mass. A computed tomography (CT) scan showed an anterior mediastinum tumor measuring $3.0 \mathrm{~cm}$ at its largest diameter. A thoracotomy was performed and a tumor identified as of thymic origin was completely removed. The gross features are of a firm nodule, lobulated, pink-grayish measuring $3.6 \times 2.4 \times 1.3 \mathrm{~cm}$. The cut section of the tumor was whitish, sparsely nodular, soft and elastic. The microscopic examination of the surgical specimen revealed a capsulated and lobulated neoplasia composed of spindle cells without cytological atypia in a storiform pattern, with an admixture of mature lymphocytes and crossed by multiple fibrous septa (Fig 1). Several foci of capsule invasion and extension to the peri-thymic fat tissue was observed (Fig 2). Immunohistochemical analyses using the avidin-biotin-peroxidase technique showed diffuse and intense immunoreactivity for cytokeratins (MNF116) in the spindle cell epithelial component (Fig 3), as well as strong and diffuse cytoplasmic positivity for CD3 in surrounding T lymphocytes (Fig 4). Scattered spindle cells expressed $\mathrm{CD} 20$ in their cytoplasm. The histological and immunohistochemical diagnosis was medullary thymoma (Marino and Müller-Hermelink) stage II1 (Masaoka). The patient recovered well after the surgery but prednisone and anticholinesterasic drugs were still required for symptomatic control. In the clinical evaluation, the patient had no clinical evidences of hypogammaglobulinemia or red cell aplasia.

\section{DISCUSSION}

Thymoma is the most common tumor of anterior-superior mediastinum. Strictly defined, thymomas are composed of cytologically bland, neoplastic, thymic epithelial cells admixed with a variable component of benign lymphocytes ${ }^{2}$.

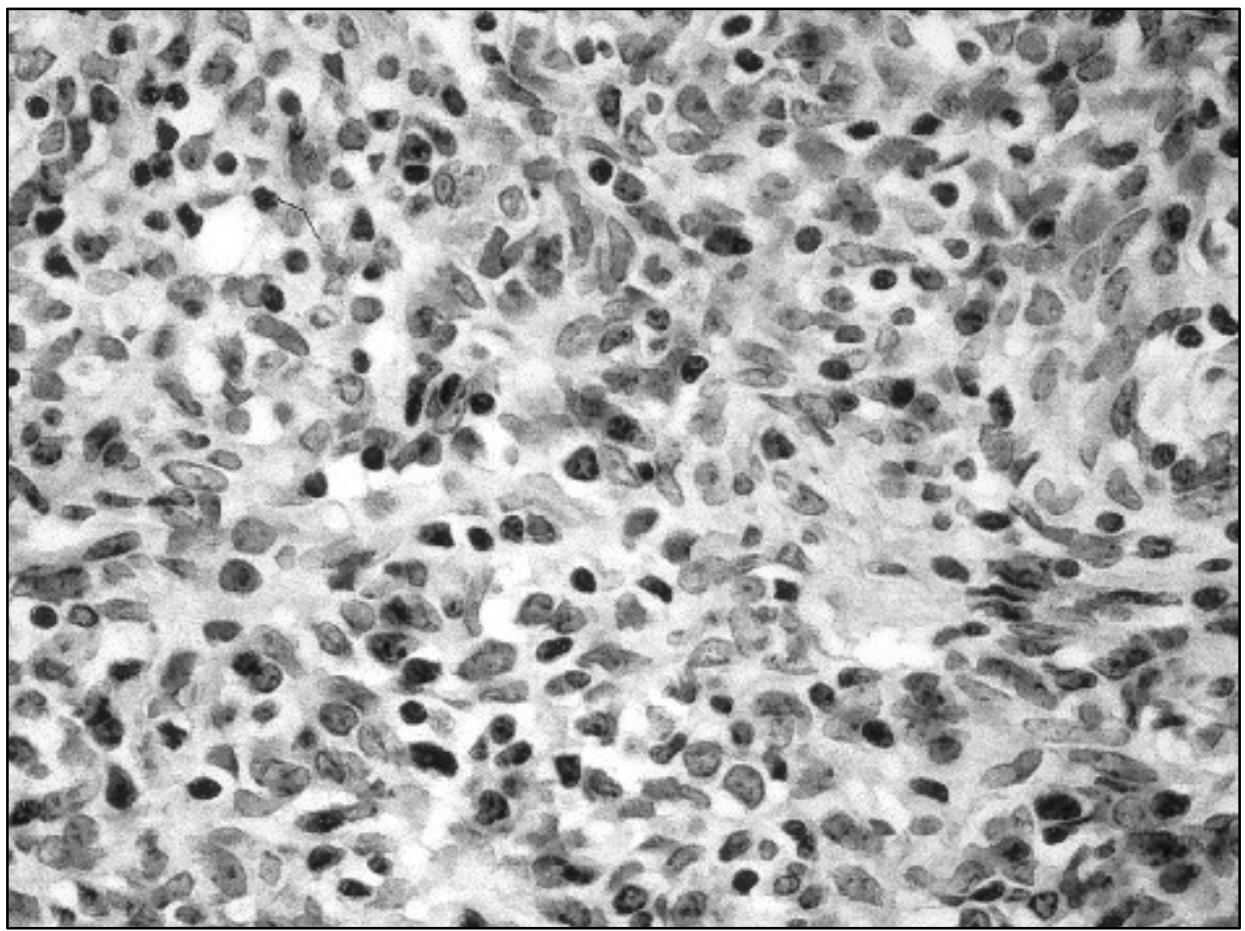

Fig 1. Photomicrography of medullary thymoma composed of spindle epithelial cells admixed with mature lymphocytes $(H E)$. 


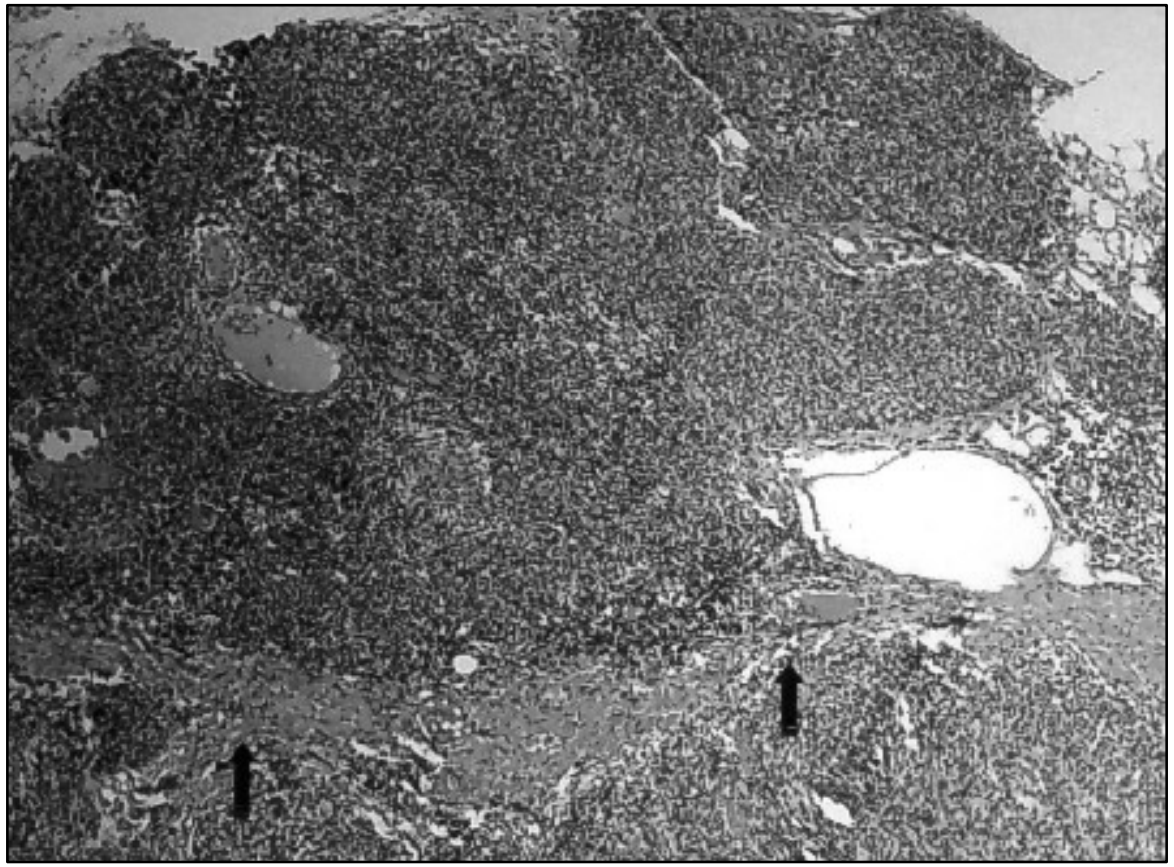

Fig 2. Capsular and perithymic tissue invasion. Note the fibrovascular capsule (arrow) infiltrated by tumor cells $(H E)$.

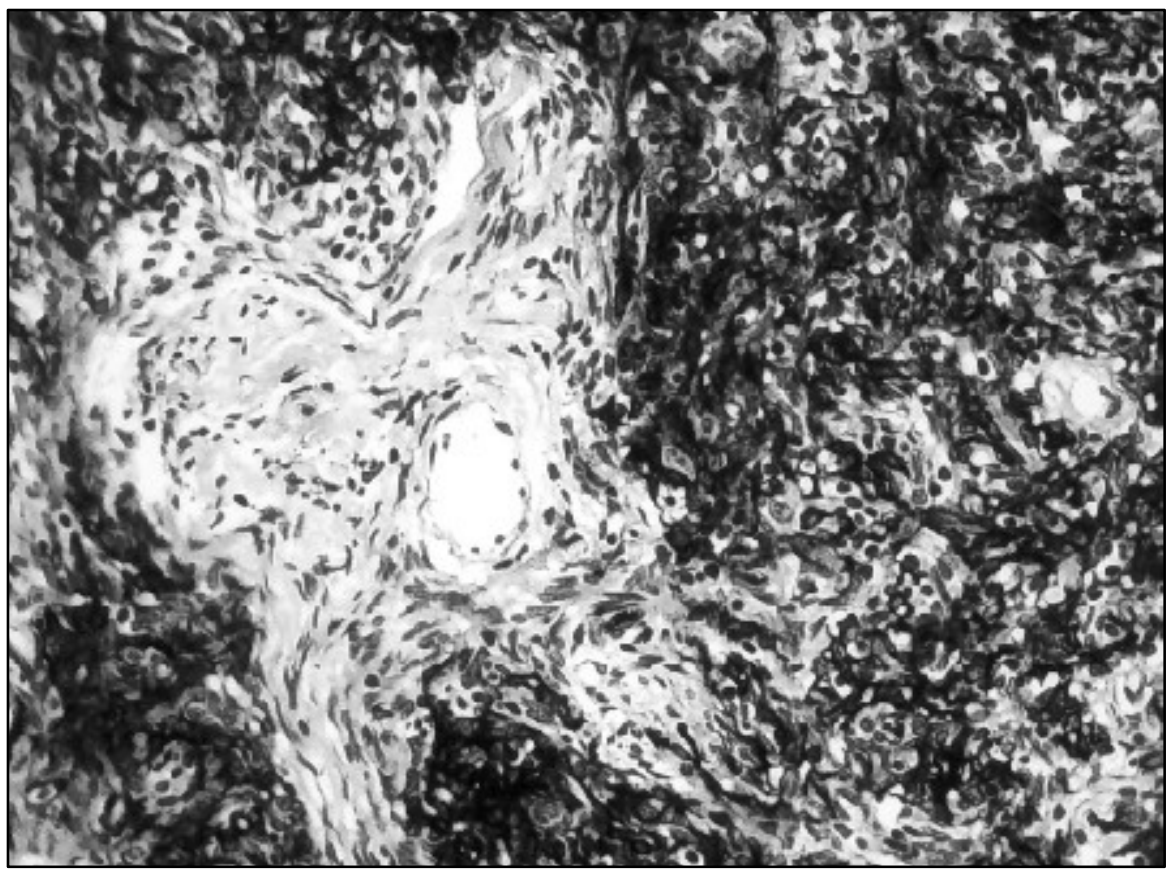

Fig 3. Photomicrography showing intense cytoplasmic positivity for cytokeratin (MNF116) in the spindle epithelial cells. (ABC-DAB). 


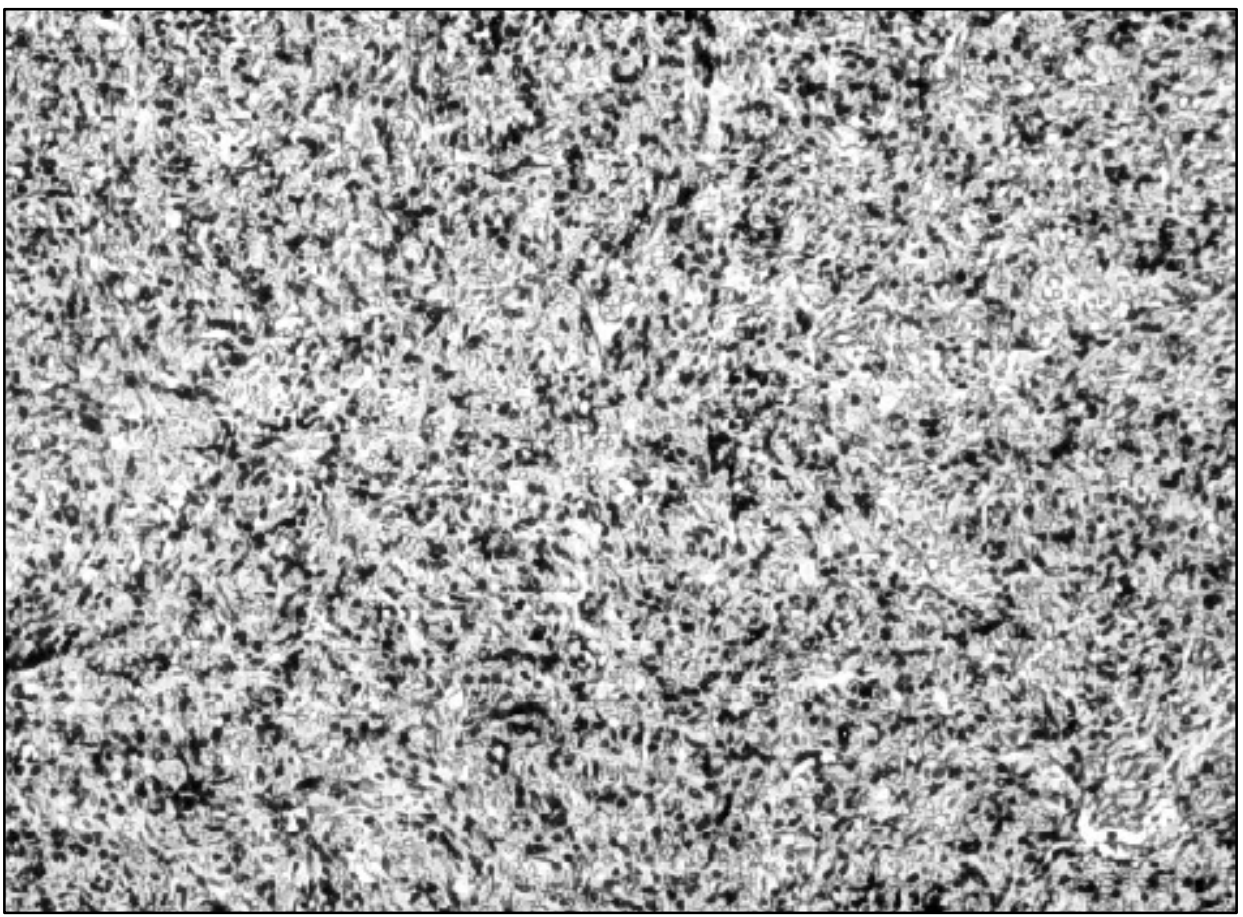

Fig 4. Photomicrography showing T lymphocytes (CD3 positive) admixed with the neoplastic epithelial cells. $(A B C-D A B)$.

Immunohistochemical evaluation of the epithelial component shows variable positivity for cytokeratins $8,13,16$, and 19, carcinoembryonic antigen, epithelial membrane antigen, Leu-7, neuron specific enolase, and focal positivity for $\mathrm{CD} 20^{5}$. The lymphoid component of thymomas presents a wide immunohistochemical profile, including markers of thymic cortical cells, such as CD1, CD2, CD3, CD4, CD5, CD7, and CD8; as well as terminal deoxynucleotidyl transferase (TdT), and CD995.

The observation that thymus is intrinsically associated with the pathogenesis of MG dates fifty years back $^{6}$. Blalock noted that extirpation of thymic tumors in patients with MG often led to dramatic neurologic improvement. Indeed thymic abnormalities are found in the majority of the MG patients. Approximately $70 \%$ of patients with this disease have thymic lymphoid folicular hyperplasia, $10 \%$ have neoplastic thymoma and the remaining $20 \%$ show thymic atrophy ${ }^{4}$.

The occurrence of MG in patients with thymoma usually precedes the diagnosis of the thymic neoplasm. In the Mayo Clinic series of 283 thymoma cases, $40 \%$ of the patients presented tumorrelated symptoms at the time of the diagnosis. Forty-six percent of the patients with thymoma developed miastenia gravis; $29 \%$ out of these patients had symptoms directly related to their thymomas ${ }^{2}$.

A great amount of experimental studies endorse the hypothesis that initial and essential steps on the pathogenesis of MG take place within the thymus. The thymus is the central immune organ in which immunologic self-tolerance is generated, where $\mathrm{T}$ lymphocytes proliferate and differentiate to reach functional maturity and antigen specificity. In addition, within the thymus, self-reactive, potentially auto-aggressive $\mathrm{T}$ cell clones are purged from the immune repertoire to establish self tolerance ${ }^{4}$.

Recent pathological data suggest that intratumoral expression of a $153-\mathrm{kD}$ midsize neurofilament (NF-M), which contains an acetylcholine receptor-like epitope, is the myasthenogen 
determinant that would trigger the MG in patients with thymoma ${ }^{7}$. At present, this NF-M is the only tumor marker that is significantly associated with thymoma in paraneoplastic MG. Increased T-cell responses to NF-M in patients with paraneoplastic MG might be the result of an abnormal positive selection of immature T cells within thymomas, caused by the expression of NF-M in neoplastic thymic epithelial cells. However, evaluation of the transcription of muscular or neuronal acetylcholine receptor (AChR) subunit genes in thymomas have brought evidences that there are heterogeneity in the etiology of paraneoplastic MG among patients with different histological subtypes of thymomas ${ }^{8}$. According to Nenninger et al., the cortical and mixed thymomas generate naive but potentially autoaggressive T cells, that could be actively immunized inside the tumor, contributing to the genesis of $\mathrm{MG}^{9}$. However, the definitive etiologic factors that trigger potentially auto-reactive $\mathrm{T}$ cells and make them actively myasthenic remain to be defined ${ }^{9}$.

The classification of Marino and Müller-Hermelink distinguishes between medullary thymomas, mixed thymoma, predominantly cortical thymoma, cortical thymoma, well-differentiated thymic carcinoma, and other rare types of thymic carcinoma ${ }^{3}$. These different types of thymoma differ significantly with respect to invasiveness, prognosis, and association with MG. The cortical thymomas affect younger patients and are more frequently associated with MG than medullary thymomas. The cortical subtype also show a propensity to be invasive in nature, whereas the medullary thymomas usually behave as benign tumors. In respect to association with thymomas in more than $80 \%$ of the cases of thymoma associated with MG, the tumors are classified as well-differentiated thymic carcinomas, cortical thymomas, or predominantly cortical thymomas. By contrast, medullary and mixed thymomas only rarely are associated with $\mathrm{MG}^{10}$. Maggi et al. found an incidence of only $0,04 \%$ of myasthenia gravis in medullary thymomas patients ${ }^{11}$, while Ricci et al. found an incidence as high as $11 \%{ }^{1}$. These findings have not been fully explained yet.

In summary, we describe a case of a rare variant of thymoma associated with MG, supporting the relationship between this variant of thymoma and MG. Another peculiar feature of the present case is the presence of several foci of capsular and peri-thymic fat invasion which constitutes an infrequent finding in this histological type of thymoma.

\section{REFERENCES}

1. Ricci C, Rendina EA, Pescarmona EO, et al. Correlation between histological type, clinical behaviour, and prognosis in thymoma. Thorax 1989;44:455-460.

2. Lewis JE, Wick MR, Scheithauer BW, et al. Thymoma: a clinicopathological review. Cancer 1987;60:2727-2743.

3. Marino M, Müller-Hermelink HK. Thymoma and thymic carcinoma: relation of thymoma epithelial cells to the cortical and medullary diferentiation of the thymus. Virchows Arch 1985;407:119-149.

4. Hohlfeld R, Wekerle H. The thymus in myasthenia gravis. Neurol Clin N Am 1994;12:331-342.

5. Kornstein MJ. Tumors of the mediastinum and thymus. In Silverberg SG, DeLellis RA, Frable WJ. Principles and practice of surgical pathology and cytopathology. 3.Ed. New York: Churchill Livingstone: 1997:1517-1562.

6. Blalock A. Thymectomy in the treatment of myasthenia gravis: report of twenty cases. J Thorac Surg 1944;13:316-325.

7. Schulz A, Hoffacker V, Wilisch A, et al. Neurofilament is an autoantigenic determinant in myasthenia gravis. Ann Neurol 1999;46:167-175.

8. Wilish A, Gutsche S, Hoffacker V, et al. Association of acetylcholine receptor alpha-subunit gene expression in mixed thymoma with myasthenia gravis. Neurology 1999;52:1460-1466.

9. Nenninger R, Schulz A, Hoffacker V, et al. Abnormal thymocyte development and generation of autoreactive $\mathrm{T}$ cells in mixed and cortical thymomas. Lab Investig 1998;78:743-753.

10. Kirchner T, Schalke B, Buchwald J, et al. Well-diferentiated thymic carcinoma: an organotypical low-grade carcinoma with relationship to cortical thymoma. Am J Surg Pathol 1992;16:1153-1169.

11. Maggi G, Casadio C, Cavallo A, et al. Thymoma: results of 241 operated cases. Ann Thorac Surg 1991;51:152-156. 